\title{
Inactive Form of Erythrocyte Carbonic Anhydrase B in Patients with Primary Renal Tubular Acidosis
}

\author{
TAKAHITO KonDO, First Department of Internal Medicine, Hokkaido University \\ School of Medicine, Sapporo 060 Japan \\ NAOYUKI TANIGUCHI, Department of Environmental Medicine, the Graduate \\ School of Environmental Science, Hokkaido University, Sapporo 060 Japan \\ KazuYa Taniguchi, Department of Pharmacology, School of Dentistry, \\ Hokkaido University, Sapporo 060 Japan \\ ICHIRO MATSUDA, Department of Pediatrics, Kumamoto University School of \\ Medicine, Kumamoto 860 Japan \\ Makoto Murao, Department of Medicine, Hokkaido University School of Medicine, \\ Sapporo 060 Japan
}

\begin{abstract}
A B S TRACT Evidence was found for an inactive form of carbonic anhydrase type $B$ in the erythrocytes of two children with primary renal tubular acidosis. The addition of zinc chloride to hemolysates from these patients resulted in a marked increase in the activity of this enzyme. No such effect was noted with hemolysates of control subjects. No significant differences were observed in the zinc levels of hemolysates of these patients and of normal individuals. However, the level of zinc in the carbonic anhydrase B isolated from one of these patients was low, suggesting a modified form of the enzyme. The restoration of activity upon the addition of zinc was reversed by ethylenediamine tetraacetate, but no such effects were noted for the carbonic anhydrase $B$ of normal individuals. Thus the abnormal carbonic anhydrase $B$ has decreased zinc binding.

The ultraviolet difference spectrum of the carbonic anhydrase B of normal individuals and that of a patient showed a peak at $305 \mathrm{~nm}$ which decreased upon the addition of zinc. The abnormal form of carbonic anhydrase B was not distinguishable from that of normal individuals by either immunological or electrophoretic criteria.
\end{abstract}

\section{INTRODUCTION}

Carbonic anhydrases (EC 4.2.1.1.) which catalyze the reversible hydration of $\mathrm{CO}_{2}$ (1) play an important role in $\mathrm{CO}_{2}$ gas transport and acid/base equilibrium. These enzymes have zinc in their active centers.

\footnotetext{
Received for publication 8 March 1978 and in revised form 1 May 1978.
}

There are two major carbonic anhydrase isozymes designated as the B (CA-B $)^{1}$ and $\mathrm{C}(\mathrm{CA}-\mathrm{C})$ types. They show no immunological cross reactions (2) and their synthesis is controlled at different genetic loci $(3,4)$. A quantitative immunochemical estimation of these isozymes was established by Funakoshi and Deutsch (2), and it has been reported that although the level of CA-B in human erythrocytes varies considerably under certain pathological or physiological conditions (5-11), no significant changes occur in the levels of CA-C. These immunological measurements reflect the total amount of the active and inactive enzyme protein in human erythrocytes. We have previously compared the results of a kinetic estimation of the CA-Bdependent esterase activity by an immunoadsorbent method with an immunochemical estimation of the levels of CA-B and simultaneously determined the specific activity (units per milligram of CA-B) of this enzyme (6). In the present study we present evidence for the presence of an inactive form of erythrocyte CA-B in patients with renal tubular acidosis (RTA) with the above described enzymic and immunologic techniques.

\section{METHODS}

Case reports. The properties of the erythrocyte carbonic anhydrases of two children with metabolic acidosis from unrelated Japanese families were investigated. Some general data on their blood electrolytes and the urea levels of these hyperchloremic acidotic patients are presented in Table I. Some pertinent clinical data on these children follow.

Case 1. The patient was a 3-year-old male with growth

${ }^{1}$ Abbreviations used in this paper: apo-CA-B, apocarbonic anhydrase B type; CA-B, carbonic anhydrase B type; CA-C, carbonic anhydrase $C$ type; RTA, renal tubular acidosis. 
TABLE I

Blood Data of Two Patients with Primary RTA

\begin{tabular}{lcc}
\hline & Case 1 & Case 2 \\
\hline Sodium, meq/liter & 139.0 & 145.0 \\
Potassium, meq/liter & 5.3 & 3.5 \\
Chloride, meq/liter & 118.0 & 120.0 \\
Calcium, mg/dl & 4.5 & 6.7 \\
Phosphorus, mg/dl & 8.0 & 6.5 \\
pH & 7.23 & 7.22 \\
Bicarbonate, meq/liter & 11.8 & 9.5 \\
PCO, mm/Hg & 21.4 & 24.0 \\
Urea nitrogen, mg/dl & 22.0 & 15.5 \\
\hline
\end{tabular}

retardation in which severe hyperchloremic acidosis was noted 17 days after birth. The following studies were performed at 2 yr of age. There was no glucosuria or aminoaciduria present in urine and creatinine clearance was $126 \mathrm{ml} / \mathrm{min}$ per $1.73 \mathrm{~m}^{2}$ body surface. Tubular reabsorption of phosphate was $99 \%$ and the maximum concentration ability test was recorded at the specific gravity of 1,012 . After ammonium chloride was given orally in a dose of $0.1 \mathrm{~g} / \mathrm{kg}$ body weight (12), a fixed high urinary $\mathrm{pH}$ (above 7.38) was observed when serum bicarbonate concentration was reduced to $9.8 \mathrm{meq} / \mathrm{liter}$, suggesting primary RTA (13). No nephrocalcinosis was noted on roentgen analysis.

Case 2. The patient was a 3-yr-old male with growth retardation in which metabolic acidosis was noted at 3 mo of age. The following data were obtained at $2 \mathrm{yr}$ of age. The patient evidenced hyperchloremic acidosis. His urine showed no sign of glucosuria or aminoaciduria, and his normal glomerular filtration rate was $93.0 \mathrm{ml} / \mathrm{min}$ per $1.73 \mathrm{~m}^{2}$ body surface. Phenolsulfonphthalein was $45 \%$ at $15 \mathrm{~min}$, maximum concentration ability test was 1,014 , and there was no nephrocalcinosis. An ammonium chloride loading test was not performed because of parental objection. The alkaline urine (pH 7.21-7.37) and the serum bicarbonate levels (9.52-12.0 meq/liter) suggested a diagnosis of primary RTA (13).

To control acidosis these two children were treated with a base supplement of $4 \mathrm{meq} / \mathrm{kg}$ per day, consisting of sodium bicarbonate and buffered citrate solution for $2 \mathrm{yr}$.

Subjects. The erythrocytes of these patients and their families, along with those of 25 healthy children (2-14 yr of age) and 10 healthy adults $(20-40 \mathrm{yr}$ of age), were utilized as controls.

Preparation of blood samples. Heparinized, fresh, venous blood was centrifuged at low speed to remove the erythrocytes, and the packed cells were washed two times with 10 vol of $0.9 \%$ saline by centrifugation. $2 \mathrm{vol}$ of deionized water were then added to the packed cells and the material was frozen $\left(-20^{\circ} \mathrm{C}\right)$ and thawed $\left(37^{\circ} \mathrm{C}\right)$ to effect hemolysis. The stroma was removed by centrifugation at $10,000 \mathrm{~g}$ for $30 \mathrm{~min}$. The hemoglobin content of each hemolysate was measured by the cyanmethemoglobin method (14) and then adjusted to $\cong 3 \%$ for use in the enzymic and immunological assays.

Determination of the levels of CA-B and CA-C. CA-B and CA-C isozymes were assayed according to a single radial immunodiffusion technique (15) with a slight modification of the method described by Funakoshi and Deutsch (2). The CA-B and CA-C standards employed were purified by methods previously reported (16). Specific antisera to CA-B and CA-C were obtained by immunization of individual horses, with antigens being employed as in previous studies (17). The levels of CA-B and CA-C are expressed as milligrams of enzyme per grams of hemoglobin.

Assay of enzyme activity. The esterase activity of the carbonic anhydrase was measured by a slight modification of Armstrong et al. (18) with $1 \mathrm{mM} p$-nitrophenyl acetate as substrate. A unit of enzyme activity releases $1 \mu \mathrm{mol}$ of $p$ nitrophenol per min at $25^{\circ} \mathrm{C}$.

The specific activity of $C A-B$ and $C A-C$. A modification of the immunoadsorbent method of Axen et al. (19) was employed to determine the specific activity of CA-B and CA-C as described previously (6). Affinity columns of Sepharose 4-B (Pharmacia Fine Chemicals, Piscataway, N. J.) coupled with anti-human CA-B horse IgG and with antihuman CA-C IgG were utilized for the determination of the specific activity of these isozymes. This was expressed as units per milligram of isozyme.

Experiment of $\mathrm{Zn}^{2+}$ addition. Different levels of $\mathrm{ZnCl}_{2}$ in $0.45 \%$ bovine serum albumin, $4.5 \mathrm{mM}$ Tris- $\mathrm{HCl}$ buffer, $\mathrm{pH}$ 7.4 , were incubated at $37^{\circ} \mathrm{C}$ for several hours containing $5 \mu \mathrm{M}$, purified or crude enzyme. Absorbance measurements and determinations of enzyme activity were made with a Hitachi model 624 spectrophotometer (Hitachi, Ltd., Co., Tokyo, Japan).

Apocarbonic anhydrase B (apo-CA-B). Apo-CA-B was obtained from purified holo-CA-B of normal individuals as described by Lindskog and Nyman (16) with o-phenanthroline.

Determination of zinc concentration. The concentrations of zinc in hemolysates were determined with Hitachi model 518 atomic absorption spectrophotometer, with the dithizone method described by Malström (20).

Electrophoresis. Vertical starch gel electrophoresis was carried out in Tris-EDTA-borate $\mathrm{pH} 8.6$ buffer according to the method employed by Deutsch et al. (17). A potential gradient of $6-8 \mathrm{~V} / \mathrm{cm}$ was applied over a period of $16 \mathrm{~h}$.

Purification of CA-B. CA-B was isolated from a patient with RTA and from a normal control subject according to the method described previously (6). $1 \mathrm{ml}$ of packed blood cells was employed as starting materials. The purity of the protein isolated was checked by sodium dodecyl sulfate gel electrophoresis according to the method of Weber and Osborn (21).

Chemicals. $p$-Nitrophenyl acetate was obtained from the Sigma Chemical Co., St. Louis, Mo., and DEAE-cellulose was obtained from the Green Cross Corp., Osaka, Japan. Sepharose 4-B was obtained from Pharmacia Fine Chemicals, Inc., as previously mentioned. All reagents used were of analytical grade.

\section{RESULTS}

The level and specific activity of CA-B and CA-C in patients with primary RTA. The level of CA-B and CA-C, the total esterase activity, CA-B and CA-Cdependent esterase activity, and the specific activity of the isozymes in the erythrocytes of patients and of control subjects are summarized in Table II. In case 1 the level of CA-B was in the upper range of normal (13.4 $\mathrm{mg} / \mathrm{g} \mathrm{Hb})$ but its specific activity was low $(0.29$ $\mathrm{U} / \mathrm{mg})$ compared to normal subjects $(0.51 \mathrm{U} / \mathrm{mg})$. In case 2 the level of CA-B was within normal limits (10.1 mg/g Hb) but its specific activity was significantly lower $(0.15 \mathrm{U} / \mathrm{mg})$. Neither the level nor the specific activity of CA-C in these patients was different from those of normal subjects. 
TABLE II

The Level and Specific Activity of CA-B and CA-C in Erythrocytes

\begin{tabular}{|c|c|c|c|c|c|c|c|c|}
\hline \multirow[b]{3}{*}{ Subject } & \multirow{3}{*}{$\begin{array}{l}\text { No. of } \\
\text { cases }\end{array}$} & \multirow{2}{*}{\multicolumn{2}{|c|}{ Immunological level }} & \multicolumn{3}{|c|}{ Esterase activity } & & \\
\hline & & & & \multirow{2}{*}{$\begin{array}{c}\text { Total } \\
\text { activity }\end{array}$} & \multicolumn{2}{|c|}{ Dependent activity } & \multicolumn{2}{|c|}{ Specific activity } \\
\hline & & CA-B & CA-C & & CA-B & CA-C & CA-B & CA-C \\
\hline & & \multicolumn{2}{|c|}{$m g / g H b$} & \multicolumn{3}{|c|}{$U / g H b$} & \multicolumn{2}{|c|}{ U/mg isozyme } \\
\hline Case 1 & 1 & 13.4 & 1.40 & 9.9 & 3.9 & 6.0 & 0.29 & 4.29 \\
\hline Case 2 & 1 & 10.1 & 1.33 & 5.7 & 1.5 & 4.2 & 0.15 & 3.16 \\
\hline $\begin{array}{l}\text { Case } 1 \\
\text { Father }\end{array}$ & 1 & 16.4 & 2.25 & 16.4 & 9.3 & 7.1 & 0.57 & 3.16 \\
\hline Mother & 1 & 16.0 & 1.79 & 16.5 & 8.5 & 8.0 & 0.53 & 4.47 \\
\hline $\begin{array}{l}\text { Case } 2 \\
\text { Father }\end{array}$ & 1 & 9.0 & 1.43 & 11.2 & 6.0 & 5.2 & 0.67 & 3.64 \\
\hline Mother & 1 & 9.8 & 1.67 & 10.2 & 3.9 & 6.3 & 0.40 & 3.77 \\
\hline $\begin{array}{l}\text { Normal } \\
\text { Children }\end{array}$ & 25 & $\begin{array}{l}10.0^{*} \\
\pm 0.39\end{array}$ & $\begin{aligned} & 1.72^{*} \\
\pm & 0.09\end{aligned}$ & $\begin{array}{c}10.5^{*} \\
\pm 0.36\end{array}$ & $\begin{array}{r}5.1^{*} \\
\pm 0.36\end{array}$ & $\begin{array}{r}5.4^{*} \\
\pm 0.17\end{array}$ & $\begin{array}{c}0.51^{*} \\
\pm 0.04\end{array}$ & $\begin{array}{c}3.14^{*} \\
\pm 0.22\end{array}$ \\
\hline Adult & 10 & $\begin{array}{l}13.5^{*} \\
\pm 0.78\end{array}$ & $\begin{aligned} & 1.76^{*} \\
\pm & 0.06\end{aligned}$ & $\begin{array}{l}14.8^{*} \\
\pm 0.54\end{array}$ & $\begin{array}{r}8.9^{*} \\
\pm 0.67\end{array}$ & $\begin{array}{r}5.9^{*} \\
\pm 0.35\end{array}$ & $\begin{array}{c}0.66^{*} \\
\pm 0.05\end{array}$ & $\begin{array}{c}3.35^{*} \\
\pm 0.19\end{array}$ \\
\hline
\end{tabular}

* Values represented are expressed as mean $\pm \mathrm{SE}$.

The results of family studies of these patients shown in Table II show that the level and the specific activity of CA-B for the patients in case 1 are normal. Slightly low levels of CA-B was noted for both parents in case 2 , and a low specific activity was noted for the mother of case 2 .

Two possible reasons could account for the low specific activity of CA-B. One might relate to a structural modification which would reduce its catalytic activity without affecting cross-reactivity with antibody; the other could be explained by the presence of an inhibitor. To investigate these possibilities the following experiments were performed.

The concentration of zinc in erythrocytes of patients. The zinc content of the erythrocytes in case 1 was $34.2 \mu \mathrm{g} / \mathrm{g} \mathrm{Hb}$, and $40 \mu \mathrm{g} / \mathrm{g} \mathrm{Hb}$ in case 2. The levels in normal children ranging from 26.6 to 41.8 $\mu \mathrm{g} / \mathrm{g} \mathrm{Hb}$ with a mean $\pm \mathrm{SE}$ of $32.1 \pm 0.93 \mu \mathrm{g} / \mathrm{g} \mathrm{Hb}$ were relatively low compared to the $34.5-50.3 \mu \mathrm{g} / \mathrm{g} \mathrm{Hb}$ with a mean $\pm \mathrm{SE}$ of $41.5 \pm 0.50 \mu \mathrm{g} / \mathrm{g} \mathrm{Hb}$ values noted for adults. No differences were observed in the zinc content of the erythrocytes of the two patients and those of normal children, and the zinc content for the parents of these patients were within a normal level.

Effect of $\mathrm{Zn}^{2+}$ on the specific activity of carbonic anhydrase in hemolysate from patients. Increases in the esterase activities after the addition of $\mathrm{Zn}^{2+}$ were observed in hemolysate from patients with RTA. On the other hand, the addition of $\mathrm{Zn}^{2+}$ had no effect on the hemolysates of control subjects or those of parents of these patients. Table III shows the effect of the addition of $\mathrm{Zn}^{2+}$ on the specific activity of the isozymes. The increase in the total esterase activity was directly attributed to increases in the activity of CA-B. The specific activity of CA-B obtained after the addition of $\mathrm{Zn}^{2+}$ in these cases were fairly close to those in normal individuals. These facts suggest that about 41 and $62 \%$ of CA-B were present in an inactive form in the hemolysates of cases 1 and 2, respectively, and that the rest of CA-B was normal active form. The inactive CA-B was considered to be converted to active form by the addition of $\mathrm{Zn}^{2+}$.

Effect of EDTA on inactive CA-B. The activity restored by the addition of $\mathrm{Zn}^{2+}$ was readily lost by freezing and thawing. This suggests the possibility that the binding of $\mathrm{Zn}^{2+}$ to the inactive enzyme was weak. The effect of EDTA was studied on the inactive form of CA-B by adding to the incubation mixture various concentrations of EDTA and then incubating for $30 \mathrm{~min}$ at $37^{\circ} \mathrm{C}$ before assay. As shown in Table IV the increase in activity resulting from the addition of $\mathrm{Zn}^{2+}$ was reversed by the addition of $50 \mathrm{mM}$ EDTA. Levels of EDTA of $0.25 \mathrm{M}$ or higher were necessary to lower carbonic anhydrase activities in the hemolysates of patients and of normal subjects in which no $\mathrm{Zn}^{2+}$ had been added. To measure the relationship between the active and inactive form of CA-B, the reversibility of the inactive form to active form was also 
TABLE III

Effect of $\mathrm{Zn}^{2+}$ Addition on the Specific Activity of CA-B and CA-C

\begin{tabular}{|c|c|c|c|c|c|c|c|}
\hline \multirow[b]{2}{*}{ Subject } & \multirow[b]{2}{*}{$\begin{array}{l}\text { No. of } \\
\text { cases }\end{array}$} & \multirow[b]{2}{*}{$\begin{array}{c}\text { Added } \\
\mathrm{Zn}^{2+}\end{array}$} & \multirow[b]{2}{*}{ Total activity } & \multicolumn{3}{|c|}{ Specific activity } & \multirow[b]{2}{*}{ Inactive CA-E } \\
\hline & & & & CA-B & CA-C & $\begin{array}{c}\text { Inactive } \\
\text { CA-B }^{*}\end{array}$ & \\
\hline & & & $U / g H b$ & & /mg isozyme & & $\%$ of total \\
\hline Case 1 & & $\overline{+}$ & $\begin{array}{r}9.9 \\
12.6\end{array}$ & $\begin{array}{l}0.29 \\
0.49\end{array}$ & $\begin{array}{l}4.29 \\
4.29\end{array}$ & 0.20 & 41 \\
\hline Case 2 & & $\bar{t}$ & $\begin{array}{l}5.7 \\
8.1\end{array}$ & $\begin{array}{l}0.15 \\
0.39\end{array}$ & $\begin{array}{l}3.16 \\
3.16\end{array}$ & 0.24 & 62 \\
\hline $\begin{array}{l}\text { Case } 1 \\
\text { Father }\end{array}$ & & $\overline{+}$ & $\begin{array}{l}16.4 \\
16.4\end{array}$ & $\begin{array}{l}0.57 \\
0.57\end{array}$ & $\begin{array}{l}3.16 \\
3.16\end{array}$ & 0 & 0 \\
\hline Mother & & $\overline{+}$ & $\begin{array}{l}16.5 \\
16.5\end{array}$ & $\begin{array}{l}0.53 \\
0.53\end{array}$ & $\begin{array}{l}4.47 \\
4.47\end{array}$ & 0 & 0 \\
\hline $\begin{array}{l}\text { Case } 2 \\
\text { Father }\end{array}$ & & - & $\begin{array}{l}11.2 \\
11.2\end{array}$ & $\begin{array}{l}0.67 \\
0.67\end{array}$ & $\begin{array}{l}3.64 \\
3.64\end{array}$ & 0 & 0 \\
\hline Mother & & $\overline{+}$ & $\begin{array}{l}10.2 \\
10.2\end{array}$ & $\begin{array}{l}0.40 \\
0.40\end{array}$ & $\begin{array}{l}3.77 \\
3.77\end{array}$ & 0 & 0 \\
\hline Normal children & 25 & $\overline{+}$ & $\begin{array}{l}10.5 \pm 0.36 \ddagger \\
10.5 \pm 0.36\end{array}$ & $\begin{array}{l}0.51 \pm 0.04 \ddagger \\
0.51 \pm 0.04\end{array}$ & $\begin{array}{l}3.14 \pm 0.22 \ddagger \\
3.14 \pm 0.22\end{array}$ & 0 & 0 \\
\hline Normal adult & 10 & $\overline{+}$ & $\begin{array}{l}14.8 \pm 0.54 \ddagger \\
14.8 \pm 0.54\end{array}$ & $\begin{array}{l}0.66 \pm 0.05 \ddagger \\
0.66 \pm 0.05\end{array}$ & $\begin{array}{l}3.35 \pm 0.19 \ddagger \\
3.35 \pm 0.19\end{array}$ & 0 & 0 \\
\hline
\end{tabular}

The incubation mixture was composed of hemolysate containing $50 \mu \mathrm{M} \mathrm{CA}-\mathrm{B}, 0.45 \%$ bovine serum albumine, $\mathrm{pH}$ 7.4, $4.5 \mathrm{mM}$ Tris- $\mathrm{HCl}$ buffer, $100 \mu \mathrm{M} \mathrm{ZnCl}_{2}$ in a final volume of $1 \mathrm{ml}$. The incubation was carried out for $6 \mathrm{~h}$ at $37^{\circ} \mathrm{C}$ before assay.

* The specific activity of inactive CA-B was expressed as the difference in the specific activity before and after the $\mathrm{Zn}^{2+}$ addition.

$\ddagger$ Values are expressed as mean $\pm \mathrm{SE}$.

investigated. The assay mixture, preincubated with $\mathrm{Zn}^{2+}$, in these cases was treated with $50 \mathrm{mM}$ EDTA and dialysed against $1,000 \mathrm{vol}$ of $10 \mathrm{mM}$ Tris- $\mathrm{HCl}$, $\mathrm{pH} 7.4$, to remove EDTA, and $\mathrm{Zn}^{2+}$ was added again. The activity was completely restored thus indicating that the inactive form of CA-B has weak $\mathrm{Zn}^{2+}$ binding.

Effect of the patient hemolysate on the specific activity of normal control hemolysate. To determine if there is any factor in the hemolysates of patients that inactivates CA-B, the hemolysate from a normal control was mixed with an equal volume of hemolysate of a patient. This mixture was incubated for $6 \mathrm{~h}$ at $37^{\circ} \mathrm{C}$ and the activity was assayed. Failure to modify the specific activity of CA-B indicated that hemolysates of these patients do not inactivate CA-B. The addition of $\mathrm{Zn}^{2+}$ to the mixed hemolysate results in an increase of $17 \%$ in the specific activity of CA-B. This enhanced activity would appear to relate to the activation of the CA-B in the patient's hemolysate.

Starch gel electrophoresis of hemolysate from patients. Fig. 1 shows the starch gel electrophoretic pattern of the carbonic anhydrase in hemolysates of the two patients and of a normal control. The electrophoretic properties of the samples appear to be identical.

Purification of CA-B from erythrocyte of a patient.

TABLE IV

Effect of EDTA on the Esterase Activity of Hemolysates

\begin{tabular}{lcrrr}
\hline & & \multicolumn{3}{c}{ EDTA concentration* } \\
\cline { 3 - 5 } \multicolumn{1}{c}{ Subject } & $\mathrm{Zn}^{2+}$ Addition & \multicolumn{1}{c}{0} & \multicolumn{1}{c}{50} & 250 \\
\hline Case 1 & - & 9.9 & 9.9 & 6.9 \\
& + & 12.6 & 9.9 & 6.9 \\
Case 2 & - & 5.7 & 5.7 & 4.0 \\
& + & 8.1 & 5.7 & 4.0 \\
Normal children & - & 10.2 & 10.2 & 7.1 \\
& + & 10.2 & 10.2 & 7.1 \\
\hline
\end{tabular}

Values are expressed as the esterase activity in units per gram of hemoglobin. Each value represents the average of duplicate analyses.

* The EDTA concentrations are expressed in millimoles. 


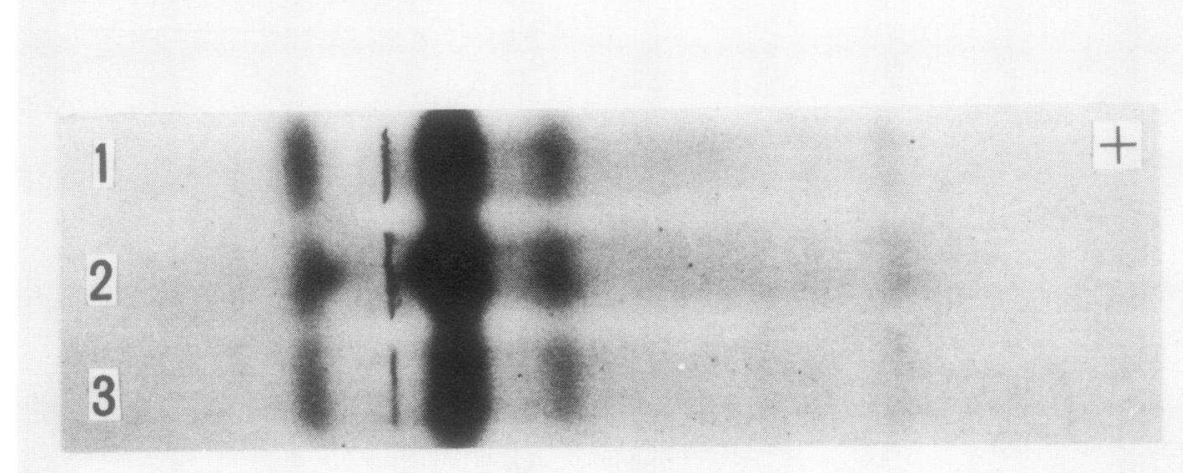

FIGURE 1 Starch gel electrophoresis of ethanol-chloroform extracts in patients with RTA. 1, case 1; 2, a normal control; 3 , case 2 .

CA-B was isolated from $1 \mathrm{ml}$ of erythrocytes of patient 1 , in a yield of $30 \%(980 \mu \mathrm{g})$ as described in Methods. An isoelectric focusing experiment showed a component with the identical isoelectric point as normal CA-B, in a $\mathrm{pH}$ 5.85. Sodium dodecyl sulfate gel electrophoresis showed a single component with the mobility of CA-B from a normal control (Fig. 2).

The activity and the amount of zinc in the purified CA-B are shown in Table V. The specific activity of the CA-B from case 1 was $0.27 \mathrm{U} / \mathrm{mg}$ as compared with $0.62 \mathrm{U} / \mathrm{mg}$ for a control. The zinc level was 1.12 $\mu \mathrm{g} / \mathrm{mg} \mathrm{CA}-\mathrm{B}$ in case 1 and $2.34 \mu \mathrm{g} / \mathrm{mg}$ in the control. These results show the presence of $0.51-\mathrm{g}$ atoms $\mathrm{Zn}$ per molecule enzyme in case 1 and 1.07 in the control. The specific activity:zinc ratio was almost the same in each case which suggests that the low specific activity of CA-B in case 1 is a result of the absence of zinc in this isozyme. This is in agreement with an immunologically active but enzymatically inactive form of CA-B in the patients.

Effect of metals on the activity of purified CA-B from erythrocyte of a patient. The purified CA-B $(5 \mu \mathrm{M})$ from case 1 was incubated with various metal ions $(10 \mu \mathrm{M})$ for $6 \mathrm{~h}$ at $37^{\circ} \mathrm{C}$, and the changes in activity were determined. The addition of $\mathrm{Zn}^{2+}$ resulted in a marked increase in the specific activity from 0.27 to $0.44 \mathrm{U} / \mathrm{mg} \mathrm{CA}-\mathrm{B}$. Activation by $\mathrm{Co}^{2+}$ and $\mathrm{Mn}^{2+}$ but not by $\mathrm{Cu}^{2+}$ was noted as shown in Table VI. The same effect of these metals was observed with apo-CA-B prepared from a normal control.
The ultraviolet difference spectrum of CA-B from a patient. The ultraviolet difference spectrum of the purified CA-B of a patient and a control had a peak at $305 \mathrm{~nm}$ as shown in Fig. 3. After incubation of the purified CA-B from case 1 with $\mathrm{Zn}^{2+}$ for 6 $\mathrm{h}$ at $37^{\circ} \mathrm{C}$, the absorbance at $305 \mathrm{~nm}$ decreased by $50 \%$. This returned to its original level after treatment with $50 \mathrm{mM}$ EDTA.

Kinetic study of the $\mathrm{Zn}^{2+}$ binding to inactive $C A-B$. The activation of the enzyme by $\mathrm{Zn}^{2+}$ was reached within $6 \mathrm{~h}$ as shown in Fig. 4. The effect of various levels of $\mathrm{Zn}^{2+}$ on the restoration of the esterase activities of the hemolysate and the purified CA-B from case 1 is shown in Fig. 5. More $\mathrm{Zn}^{2+}$ was required for maximum activation of the hemolysate than was required for the purified CA-B from the same patient. The crude hemolysate required more than an equimolar concentration of $\mathrm{Zn}^{2+}$ to obtain the maximum levels of the activation, whereas the isolated CA-B from case $1(5 \mu \mathrm{M})$ required only $2 \mu \mathrm{M} \mathrm{Zn}^{2+}$. As mentioned earlier, in case $1,41 \%$ of CA-B was present as an inactive form, therefore the $\mathrm{Zn}^{2+}$ concentration $(2 \mu \mathrm{M})$ required to obtain the maximum level of activation was considered to be that required for the inactive form. It is possible that some of the added $\mathrm{Zn}^{2+}$ was bound to other proteins in hemolysates. This raises the question why the addition of $\mathrm{Zn}^{2+}$ activated CA-B, because the hemolysates of the patients have the same level of zinc as normal children. To determine the level of protein-bound zinc, $0.3 \mathrm{ml}$ of hemolysate of patients and of normal controls was extensively 


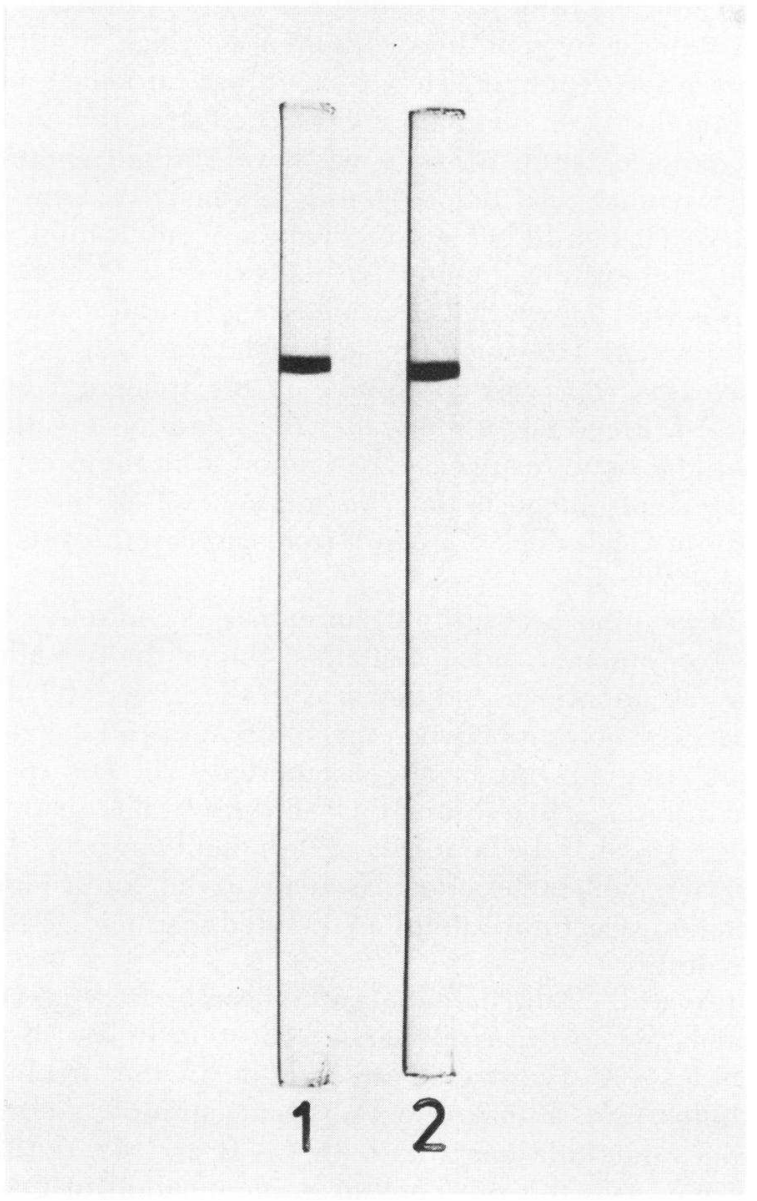

FIGURE 2 Sodium dodecyl sulfate gel electrophoresis of purified CA-B. 1, case 1; 2, a normal control.

dialyzed against 30 vol of distilled water for $72 \mathrm{~h}$. Almost $97 \%$ of the zinc in both source hemolysates was nondializable.

\section{DISCUSSION}

The presence of a mutant form of CA-B which is immunologically active but enzymatically inactive was demonstrated in two patients with primary RTA.

TABLE V

The Specific Activity and Zinc Content of Purified CA-B

\begin{tabular}{lcccc}
\hline & $\begin{array}{c}\text { Specific } \\
\text { Subject }\end{array}$ & Zactivity & $\begin{array}{c}\text { Specific } \\
\text { activity/ } \\
\text { zinc }\end{array}$ & Zinc/CA-B \\
\hline & U/mg CA-B & $\mu g / m g$ CA-B & U/mg & g atoms/30,000 \\
& & & & g CA-B \\
Case 1 & 0.27 & 1.12 & 0.24 & 0.51 \\
Control & 0.62 & 2.34 & 0.26 & 1.07 \\
\hline
\end{tabular}

The mol wt of CA-B used was 30,000 (1).
TABLE VI

Specificity of Metal Ions

\begin{tabular}{ccc}
\hline & \multicolumn{2}{c}{ Relative specific activity } \\
\cline { 2 - 3 } Metal ion & $\begin{array}{c}\text { o-Phenanthroline-treated CA-B } \\
\text { (normal source) }\end{array}$ & $\begin{array}{c}\text { Purified CA-B } \\
\text { (case 1) }\end{array}$ \\
\hline $\mathrm{Zn}^{2+}$ & 100.0 & 100.0 \\
$\mathrm{Co}^{2+}$ & 74.5 & 74.8 \\
$\mathrm{Mn}^{2+}$ & 25.0 & 24.8 \\
$\mathrm{Cu}^{2+}$ & 0 & 0
\end{tabular}

Values are expressed as the percent of the activity observed in the presence of $\mathrm{Zn}^{2+}$.

Schapira et al. reported previously the presence of a mutant form of CA-B in a family with RTA (22). The purified CA-B from this patient was unstable in $8 \mathrm{M}$ urea or high temperature $\left(56^{\circ} \mathrm{C}\right)$. In our cases the stability of the enzyme against urea or temperature was normal (data not shown).

A study of a variant form of human CA-B has also been reported by Tashian and Carter (23). They found that its esterase activity increased with the addition of $\mathrm{Zn}^{2+}$. This variant CA-B, however, was found to contain one zinc atom per molecule of enzyme. The CA-B in our cases thus appears to be a novel type of a mutant CA-B.

Funakoshi and Deutsch have reported that about $83 \%$ of erythrocyte zinc is bound to CA-B (2). Our studies of CA-B isolated from normal individuals showed it to retain $1 \mathrm{~g}$ atom of zinc per molecule and accounts for $\cong 83 \%$ of the zinc of the hemolysate. However, $40-60 \%$ of the zinc in the hemolysates of RTA patients was bound to CA-B even though the level of zinc was within normal range. Our dialysis experiment indicated that considerable zinc must be bound to proteins other than CA-B.

It has been reported that substitution of metals for zinc modifies the activity of CA-B (16). In our study, metal ions such as $\mathrm{Co}^{2+}$ or $\mathrm{Mn}^{2+}$ also activated the

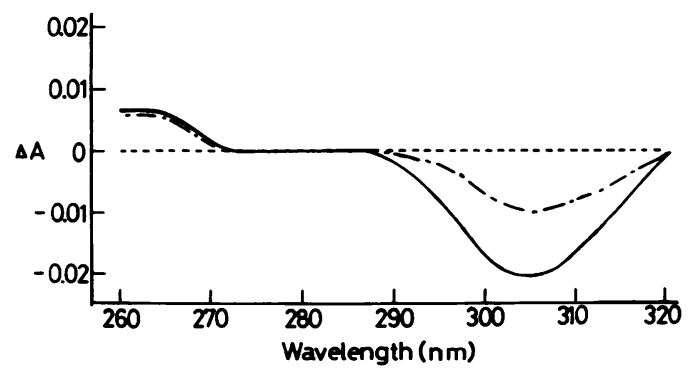

FIGURE 3 Ultraviolet difference spectra of CA-B solutions (2 $\mu \mathrm{M}$ in $0.005 \mathrm{M}$ Tris- $\mathrm{HCl}$ buffer, $\mathrm{pH}$ 7.4) were measured in 1$\mathrm{cm}$ cells at $25^{\circ} \mathrm{C}$. The solid curve represents purified normal CA-B vs. purified CA-B from case 1 . The dashed curve represents normal CA-B vs. CA-B from case 1 to which $\mathrm{Zn}^{2+}$ had been added. 


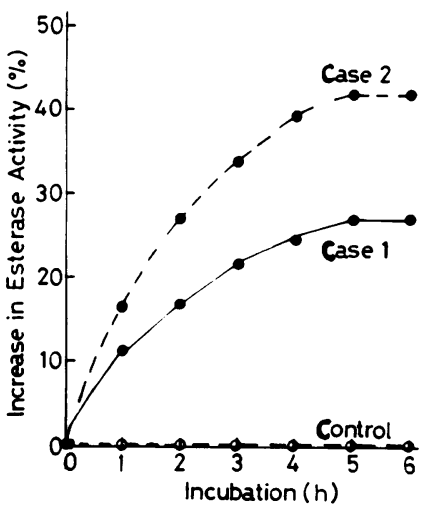

Figure 4 Effect of incubation with $\mathrm{Zn}^{2+}$ on the esterase activity of hemolysates from patients with RTA. An amount of hemolysate containing $5 \mu \mathrm{M}$ CA-B was incubated with $0.45 \%$ bovine serum albumin and $10 \mu \mathrm{M} \mathrm{ZnCl}_{2}$ in $\mathrm{pH} 7.4,4.5 \mathrm{mM}$ Tris-HCl buffer, in a final volume of $1 \mathrm{ml}$. Maximum activity was expressed as a percent of initial activity. The initial activity was $9.9 \mathrm{U} / \mathrm{g} \mathrm{Hb}$ in case $1,5.7 \mathrm{U} / \mathrm{g} \mathrm{Hb}$ in case 2 , and $10.5 \mathrm{U} / \mathrm{g} \mathrm{Hb}$ in a control, respectively. Incubation was performed at $37^{\circ} \mathrm{C}$.

variant form of CA-B as well as apo-CA-B prepared from normal blood (Table IV). It is unlikely that $\mathrm{Zn}^{2+}$ is substituted by other metals in vivo, because $50 \mathrm{mM}$ EDTA did not influence the initial activity and other data indicate that the aberrant CA-B is a zinc-free form.

Our observations suggest that erythrocyte CA-B exist in two distinct forms in these patients with RTA: $(a)$ normal native holo-form, which has one atom zinc per one molecule enzyme, and (b) inactive form which is

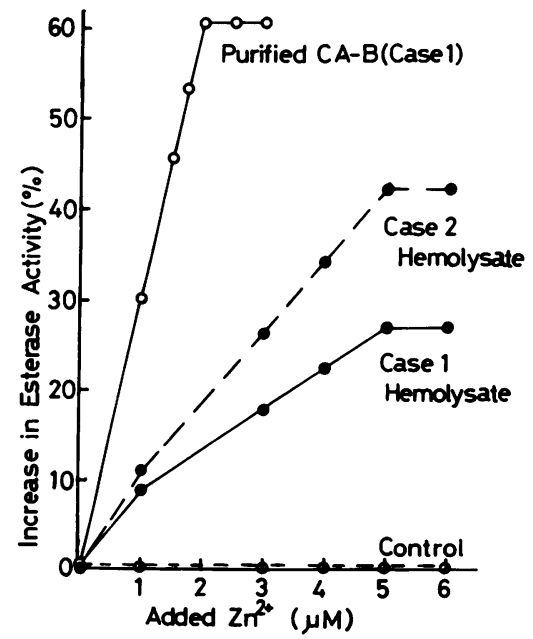

Figure 5 Effect of various concentrations of $\mathrm{Zn}^{2+}$ on the esterase activities of the hemolysates of RTA patients, of normals, and of purified CA-B from case 1 . The mixtures incubated contained $5 \mu \mathrm{M}$ CA-B and $0.45 \%$ bovine serum albumin in $\mathrm{pH} 7.4,4.5 \mathrm{mM}$ Tris- $\mathrm{HCl}$ buffer, and $\mathrm{ZnCl}_{2}$ to $6 \mu \mathrm{M}$, final volume $1 \mathrm{ml}$. Samples were incubated for $6 \mathrm{~h}$ at $37^{\circ} \mathrm{C}$. Activity was expressed as a percent of the initial activity as shown in Fig. 4. activated upon the addition of $\mathrm{Zn}^{2+}$. A modification of CA-B in the two children with RTA may have resulted from prior treatment. However, only bicarbonate and citrate had been given for $2 \mathrm{yr}$ before taking the blood specimens. Quite recently we have studied another RTA patient also demonstrating an inactive form of CA-B. This child has not received any medication, so the possibility of a drug-related effect could be excluded.

It is well known that chloride strongly inhibits CA-B activity (24). However, the hyperchloremic acidosis in our cases was well controlled by the treatment employed. Blood taken 8 mo after the initial observation gave the same results as those reported in the present study. This suggests that the presence of an inactive form of CA-B does not result from increased levels of blood chloride.

The synthesis of carbonic anhydrase is controlled by two codominant, autosomal alles. One of the two alles may be abnormal. A difference in the ultraviolet difference spectrum between the apoprotein and the zinc containing enzyme has been reported (25). The spectral difference noted for the CA-B from an RTA patient (Fig. 3) could be a result of a mutant form of this enzyme, which has a decreased affinity for $\mathrm{Zn}^{2+}$. More detailed structural studies are needed to elucidate this possibility.

It is well established that carbonic anhydrase plays a major role in renal tubular acidification in the distal tubules and hydrogen ion secretion in the proximal tubules (26). Funakoshi and Deutsch reported that kidney medulla contains both CA-B and CA-C (27). In our cases the presence of a mutant form of CA-B in erythrocytes suggests the possibility of a similar form in the kidney medulla, which may relate to the difficulty in acidification of the urine in these patients. Continuing studies in our laboratory are directed to clarification of the above findings in definitive structural modification of the unusual CA-B.

\section{ACKNOWLEDGMENTS}

The authors are grateful to professor Harold F. Deutsch, Dr. Akihiko Kawamura, Dr. Tohju Ohnishi, and Dr. Takako Maki for their valuable advice and discussion. We are also indebted to Dr. Toshio Sato for performing the zinc analysis.

This work was supported in part by a grant from the Japanese Foundation of Metabolism and Disease and a grantin-aid for Scientific Research (project no. 187033) for Naoyuki Taniguchi from the Japanese Ministry of Education.

\section{REFERENCES}

1. Lindskog, S., L. E. Henderson, K. K. Kannan, A. Lilijas, P. O. Nyman, and B. Strandberg. 1971. Carbonic anhydrase. In The Enzymes. P. D. Boyer, editor. Academic Press, Inc., New York. 5: 587-665.

2. Funakoshi, S., and H. F. Deutsch. 1970. Human carbonic anhydrase. J. Biol. Chem. 245: 2852-2856.

3. Tashian, R. E. 1969. The esterase and carbonic anhydrase of human erythrocyte. In Biochemical Methods in Red 
Cell Genetics. J. J. Yunis, editor. Academic Press, Inc. New York. 307-334.

4. Deutsch, H. F., N. Taniguchi, S. Funakoshi, and H. Hirai. 1972. Distribution of erythrocyte carbonic anhydrase B-type alles in Japanese farm horses. Biochem. Genet. 6: 255-262.

5. Funakoshi, S., and H. F. Deutsch. 1971. Human carbonic anhydrase V. levels in erythrocytes in various states. $J$. Lab. Clin. Med. 77: 39-45.

6. Kondo, T., N. Taniguchi, M. Murao, and E. Takakuwa. 1975. Estimations of active and inactive carbonic anhydrase isozyme B in human red cells. Clin. Chim. Acta. 60: 347-353.

7. Taniguchi, N., T. Sato, T. Kondo, H. Tamachi, K. Saito, and E. Takakuwa. 1975. Carbonic anhydrase isozymes, hemoglobin-F and gluthatione levels in lead exposed workers. Clin. Chim. Acta. 59: 29-34.

8. Taniguchi, N., T. Kondo, N. Ishikawa, H. Ohno, E. Takakuwa, and I. Matsuda. 1976. A solid-phase radioimmunoassay for human carbonic anhydrase B. Anal. Biochem. 72: 144-152.

9. Mondrup, M., and M. Anker. 1974. Carbonic anhydrase isozyme $B$ in the erythrocyte of uremic subjects. Clin. Chim. Acta. 51: 141-146.

10. Sell, J. E., and H. G. Petering. 1974. Carbonic anhydrases from human erythrocytes. J. Lab. Clin. Med. 84: 369-377.

11. Magid, E. 1970. Determination of erythrocyte carbonic anhydrase B and C: an aid in the diagnosis of thyroid disorders? Scand. J. Clin. Lab. Invest. 26: 257-262.

12. Wrong, O., and H. E. Davies. 1957. The excretion of acid in renal disease. Q. J. Med. 28: 259-313.

13. Rodriques-Soriano, J., and C. M. Edelman. 1969. Renal tubular acidosis. Annu. Rev. Med. 20: 363-382.

14. Van Kampen, E. J., and W. G. Zijlstra. 1961. Standardization of hemoglobinometry. Clin. Chim. Acta. 6: 538-544.

15. Mancini, G., A. O. Garbonara, and J. F. Heremans. 1965. Immunochemical quantitation of antigen by single radial immunodiffusion. Immunochemistry. 2: 235-254.

16. Lindskog, S., and P. O. Nyman. 1964. Metal-binding properties of human erythrocyte carbonic anhydrases. Biochem. Biophys. Acta. 85: 462-474.
17. Deutsch, H. F., S. Funakoshi, T. Fujita, N. Taniguchi, and H. Hirai. 1972. Isolation in crystalline form and properties of six horse erythrocyte carbonic anhydrases. J. Biol. Chem. 247: 4497-4502.

18. Armstrong, J. McD., D. V. Myers, J. A. Verpoorte, and J. T. Edsall. 1966. Purification and properties of human erythrocyte carbonic anhydrases. J. Biol. Chem. 241: 5137-5149.

19. Axen, R., J. Porath, and S. Ernback. 1967. Chemical coupling of peptides and proteins to polysaccharides by means of cyanogen halides. Nature (Lond.). 214: $1302-1304$

20. Malström, B. G. 1953. The inactivation of purified enolase with its activating ions. Arch. Biochem. Biophys. 46: 345-363.

21. Weber, K., and M. Osborn. 1969. The reliability of molecular weight determinations by dodecyl sulfatepolyacrylamide gel electrophoresis. J. Biol. Chem. 244: 4406-4412.

22. Schapira, E., Y. Ben-Yoseph, F. G. Eyal, and A. Russel. 1974. Enzymatically inactive red cell carbonic anhydrase $B$ in a family with renal tubular acidosis. J. Clin. Invest. 53: 59-63.

23. Tashian, R. E., and N. D. Carter. 1976. Biochemical genetics of carbonic anhydrase. In Advances in Human Genetics. H. Harris and K. Hirschhorn, editors. Plenum Publishing Corp., New York and London. 7: 1-56.

24. Maren, T. H., C. S. Rayburn, and N. E. Liddell. 1976. Inhibition by anions of human red cell carbonic anhydrase B: physiological and biochemical implications. Science (Wash. D. C.) 191: 469-472.

25. Henkens, R. W., and J. M. Sturtevant. 1968. The kinetics of the binding of zinc (II) by apocarbonic anhydrase. J. Am. Chem. Soc. 90: 2669-2676.

26. Maren, T. H. 1971. Unifying ideas concerning the physiology of carbonic anhydrase. In Oxygen Affinity of Hemoglobin and Red Cell Acid Base Status. M. Rorth and A. Astrup, editors. Academic Press, Inc., New York. 418-433.

27. Funakoshi, S., and H. F. Deutsch. 1971. Human carbonic anhydrases. VI. J. Biol. Chem. 246: 1088-1092. 